\title{
Verifikasi Distribusi Dosis TPS Dan Pesawat Linac Menggunakan Phantom Octavius 4D Dengan Teknik IMRT Protokol Kanker Lidah
}

\author{
Tomas Wali ${ }^{1}$, Febria Anita ${ }^{1}$ \\ ${ }^{1}$ Program Studi Fisika, Universitas Nasional, Jalan Sawo Manila, Pejaten, Jakarta Selatan \\ 12520 \\ Korespondensi : febria.anita85@gmail.com
}

\begin{abstract}
ABSTRAK. Tindakan terapi bertujuan untuk hasil yang optimal berupa kematian jaringan kangker sebanyak mungkin dan kerusakan minimal pada jaringan sehat sehingga dilakukan upaya untuk mengoptimalkan hasil pengobatan radiasi. IMRT merupakan salah satu teknik radioterapi menggunakan pesawat LINEC dengan banyak lapangan penyinaran yang menggunakan intensitas radiasi yang berbeda - beda untuk mendapatkan dosis maksimal pada organ target tumor dan dosis seminimal mungkin pada organ sehat. Verifikasi dilakukan dengan menggunakan Octavius 4D. Dari penelitian yang telah dilakukan pada 2 pasien dengan protokol kanker lidah, dimana 2 pasien dilakukan verifikasi pada setiap lapangan dan gabungan semua lapangan, Didapatkan kesesuaian piksel bagus untuk semua pasien dengan kriteria $\gamma \leq 1$ pada $5 \%$ DD, dan $3 \mathrm{~mm}$ DTA. Hasil verifikasi untuk semua lapangan penyinaran didapat kesesuaian piksel yaitu 99,7\% untuk pasien 1 dan 2 Kesesuaian piksel untuk dan pasien 2 hasil verifikasi untuk semua lapangan penyinaran didapat kesesuaian piksel yaitu 98,4 \%. Kesesuaian piksel untuk verivikasi setiap lapangan penyinaran pada pasien $1: 96,8 \%, 86,0 \%, 96,2 \%, 97,8 \%, 98,5 \%, 96,3 \%, 93,9 \%$, pasien 2 : $97,8 \%, 94,2 \%, 95,1 \%, 97,9 \%, 98,5 \%, 88,2 \%, 96,2 \%$. Perbedaan pengukuran disebabkan antara lain karena pergerakan MLC secara dinamis, tegangan arus yang tidak stabil, temperatur ruangan yang selalu berubah - ubah dan daerah dosis rendah.
\end{abstract}

Kata kunci : IMRT, Verifikasi Octavius 4D, Kanker Lidah

\begin{abstract}
Therapy aims is to obtain results to kill cancer tissue with minimal damage in healthy tissue, so we need to optimize the radiation treatment. IMRT is one of radiotherapy technique using a linear accelerator with a lot of radiation field segments with different radiation intensity to get the maximum dose in the target organ tumor and minimal dose to healthy organs. Before the irradiation is done to the patient, it is required to verify the TPS calculations on the actual situation. The verification is done using Octavius 4D. During this study we had been performed measurement for 2 patients with protocol cancer tongue, which consist of 2 patients verified on each field and composite field and 2 patients verified using composite field. Each measurement points must pass dosimetry criteria $\gamma \leq 1$ at $5 \% \mathrm{DD}$, and $3 \mathrm{~mm}$ DTA. Verification for composite field passing level are 99,7 \%, for patient number 1 and for patient number $2: 98,4 \%$ respectively. Passing level for each field irradiation on patient 1 are 96.8\%, 86,0\%, 96,2\%, 97,8\%, $98,5 \%, 96,3 \%, 93,9 \%$ patient $2 ; 97,8 \%, 94,2 \%, 95,1 \%, 97,9 \%, 98.5 \%, 88,2 \%, 96,2 \%$. Measurement discrepancy can be caused by the measurement difference is caused partly because the movement MLC dynamically stable voltage dud, always room temperature fluctuations and low-dose region.
\end{abstract}

Keywords : IMRT, Verification, Octavius 4D, Cancer Tongue

\section{PENDAHULUAN}

Kanker adalah penyakit yang terjadi akibat pertumbuhan sel yang tidak terkontrol yang berubah menjadi sel abnormal dan menyebar ke jaringan tubuh lainnya sehingga menyebabkan kerusakan pada jaringan tubuh yang lain. Kanker lidah adalah suatu tumor yang terjadi di dasar mulut, kadang-kadang meluas kearah lidah dan menyebabkan gangguan mobilitas lidah dan bisa disembuhkan dengan memberi terapi seperti radioterapi [1].

Radioterapi adalah suatu perlakuan atau treatment terhadap penyakit tumor ganas atau kanker dengan menggunakan radiasi pengion, seperti sinar-X, sinar gamma atau electron berenergi 
tinggi. Radioterapi adalah salah satu pengobatan penyakit kanker dengan menggunakan radiasi foton yang akan membunuh sel kanker sehingga sel kanker tidak akan berkembang atau menyebar ke jaringan lainnya. Selain sel kanker yang terkena radiasi, jaringan sehat disekitar sel kanker akan terkena radiasi sehingga sel-sel di jaringan normal akan rusak. Oleh karena itu, diperlukan suatu sistem yang mengatur perencanaan radioterapi yang disebut Treatment Planning System (TPS). Pemanfaatan suatu teknologi selain mempunyai dampak positif terdapat juga dampak negatif. Dampak negatif akan muncul bila melakukan tindakan diluar prosedur yang berlaku. Dampak negatif terburuk adalah terjadinya kecelakaan.

Beberapa kasus kecelakaan radiasi yang terkait dengan pesawat teleterapi telah terjadi di belahan dunia ini termasuk di Indonesia. Kasus kecelakaan berkenaan dengan pesawat. Radioterapi LINAC (Linear Accelerator) biasanya berawal dari berkas radiasi yang keluar tidak sesuai yang diinginkan pada saat akan menyinari pasien. Untuk membuat pendosisan yang akurat antara hasil perhitungan dosis menggunakan Treatment Planning System (TPS) dan dilapangan dengan menggunakan Intensity Modulated Radiation Therapy (IMRT) harus dilakukan verifikasi[2]. Pemberian dosis optimum pada penyinaran radioterapi sangat berguna untuk mencapai keberhasilan pengobatan. Oleh karena itu perlu dilakukan verifikasi distribusi dosis TPS dan di dalam ruangan pesawat LINAC sebagai salah satu fungsi kendali kualitas dan jaminan kualitas.

\section{METODE DAN BAHAN}

Dalam penelitian ini pesawat linac yang akan digunakan adalah pesawat linac Elektra milik RSGP, memproduksi sinar foton 6 MV, CT Scan GE Discovery DSTE type GE MX 200 CT dengan nomor seri 158594G12 dengan kemampuan 8 slice, Phantom menggunakan solid water, Ion Chamber farming Octavius 4D, Komputer kalibrasi, Komputer TPS Elektra $\mathrm{X} 10$, Verisoft patient plan verification software.

Langkah pertama Octavius di scan dengan memberikan tanda berupa marker pada titik tengah, pinggir kanan dan pinggir kiri sebagai acuhan verifikasi di TPS. Data CT Scan Octavius 4D diberikan protokol rancangan penyinaran untuk pasien kangker lidah IMRT dengan membuat sudut gentry $0^{0}$ dan semua sinar terpusat pada isosenter.

Data yang diperoleh akan diolah di komputer TPS dan dihitung berapa estimasi distribusi dosis dengan cara memberi estimasi dosis radiasi mulai $270 \mathrm{cGy}$ untuk merah, $205 \mathrm{cGy}$ untuk orange, $140 \mathrm{cGy}$ untuk kuning, 75 cGy untuk hijau, dan $10 \mathrm{cGy}$ untuk biru.Terdiri dari dua pasien dengan klinis kanker lidah dilakukan verifikasi untuk setiap lapangan penyinaran dan akumulasi lapangan penyinaran.

Pengambilan data di ruang pesawat linac dilakukan dengan teknik Source to Surface Distance (SSD) $100 \mathrm{~cm}$ dari gantry ke arah Octafius 4D. Jarak antara isocenter dengan permukaan 2,8 cm maka SSD yang digunakan untuk paparan Octavius adalah 97,2 cm. Slope diletakan diatas meja linac sebagai faktor scatter sebanyak 5 buah, sedangkan Octavius 4D diletakan diatas slope. Slope ditambah 2 buah bertujuan untuk memberi jarak dari permukaan dengan isocenter minimal $1,5 \mathrm{~cm}$.

Pengaturan sudut planning sinar linac menjadi 00 diatur sesuai dengan planning TPS. Setelah dilakukan ekspose maka hasil akan dikirim dibagian computer kalibrasi. Hasil antara data yang berada di TPS dan data yang dilakukan di ruangan linac akan dibandingkan di komputer kalibrasi untuk diverifikasi dan untuk mengetahui hasil distribusi dosis radiasi dan menentukan deviasi antara distribusi dosis di TPS dan di dalam ruang pesawat linac.

Tahapan penelitian yang dilakukan adalah sebagai berikut, membuat distribusi di TPS, Scan Phantom Octavius 4D seperti terlihat pada gambar 1, Isocenter dibuat pada komputer TPS X10 dengan obyek Octavius 4D menggunakan teknik protocol penyinaran kanker lidah dengan penyudutan pesawat linac $00 \mathrm{c}$. Hasil yang didapat berupa distribusi dosis dengan 270 cGy untuk merah, 205cGy untuk orange, 140 cGyuntuk kuning, 75 cGy untuk hijau dan 10 cGy untuk biru. 


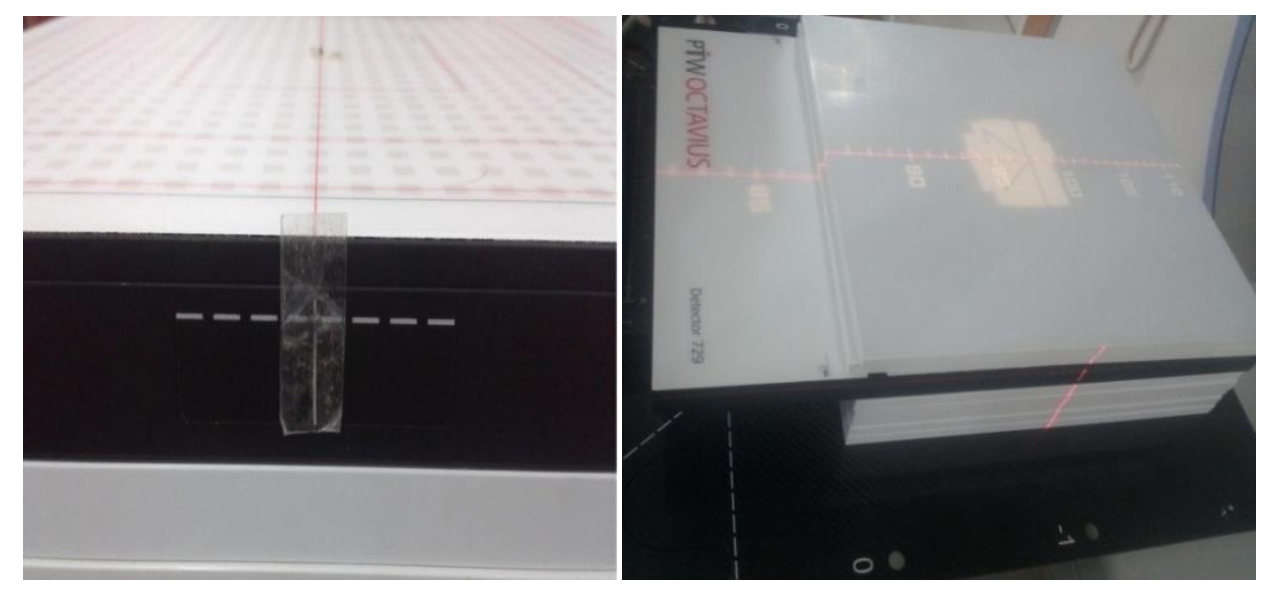

GAMBAR 1. Proses Scan Phantom Octavius 4D (Dokumen Pribadi)
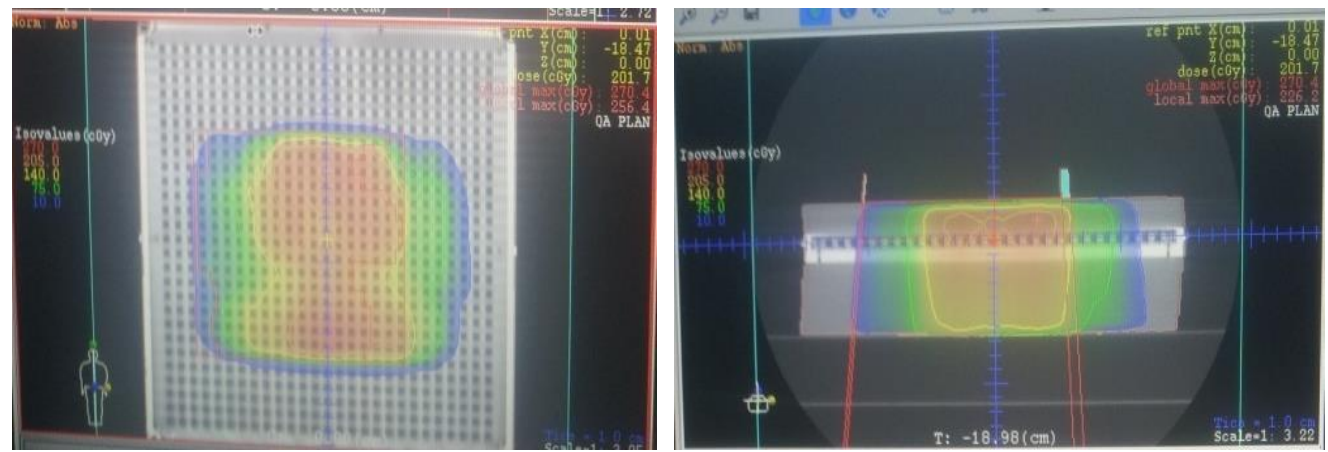

GAMBAR 2. Hasil perhitungan distribusi menggunakan Octavius 4D pada TPS di RSGP Jakarta (Dokumen Pribadi)

Selanjutnya melakukan paparan radiasi pada Octavius 4D, sudut penyinaran linac $0^{0}$, Phantom slope 5 buah dengan ketebalan $2 \mathrm{~mm}$ dan 2 buah phantom slope dengan ketebalan $1 \mathrm{~mm}$, menyiapkan slope phantom sebanyak 5 buah dan diletakkan pada meja linac sehingga dapat diperoleh ketebalan $10 \mathrm{~mm}$, kemudian diletakkan phantom Octavius 4D dan diatas phanthom Octavius ditumpuk lagi dengan slope phantom 2 tumpuk dengan ketebalan 1mm, sambungkan kabel Octavius 4D pada perangkat electrometer, kabel power, dan kabel penghubung di sambungkan dengan komputer kalibrasi terlihat pada gambar 3, total beam linec 7 kali dengan total 51 segment dan total MU 650,74, berikutnya adalah membandingkan distribusi dosis antara data pada TPS dan data pada lapangan dengan menggunakan softwere Verisoft patient plan verification software.

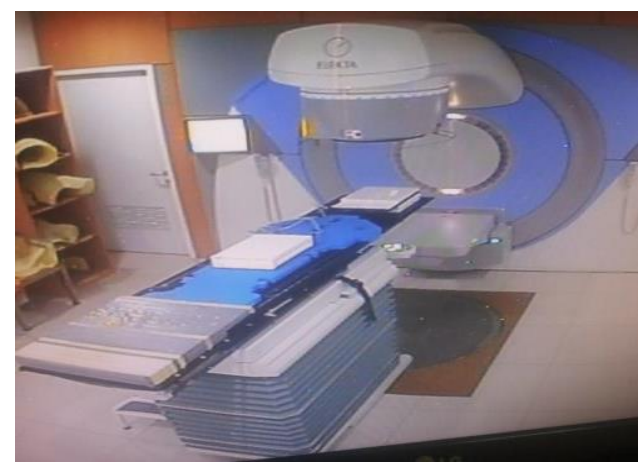

GAMBAR 3. Proses paparan radiasi Octavius 4D di RSGP Jakarta (Dokumen Pribadi)

Data CT Planning pasien dengan kasus kanker lidahakan di olah di komputer TPS untuk menentukan SSD dan planning penyinaran. Langkah pertama penelitian adalah membuat sebarandistribusi dosis dan estimasi dosis yang akan diterima pasien, setelah itu hasil data akan dikirimkan kekomputer kalibrasi untuk di verifikasi. Penggunaan slop bertujuan untuk faktor scatter, kemudian Octavius 4D dihubungkan dengan elektrometer dan komputer kalibrasi. 
Data hasil pengukuran yang diperoleh akan langsung diketahui pada komputer kalibrasi secara real time. Data yang dianalisis dalam penelitian ini merupakan data distribusi dosis pada perhitungan TPS dan hasil pengukuran Octavius 4D yang akan di verifikasi pada komputer kalibrasi menggunakan Verisoft patient plan verification softwere untuk setiap lapangan penyinaran dan akumulasi lapangan penyinaran dengan kriteria nilai $(\gamma \leq 1)$ pada $5 \%$ DD, dan 3 mm DTA.

\section{HASIL DAN PEMBAHASAN}

Verifikasi penyinaran IMRT yang dilakukan pada setiap lapangan penyinaran, hasilnya pada perangkat lunak verisoft patient plan verification software terlihat perbandingan distribusi dosis dari verifikasi penyinaran IMRT pada setiap lapangan penyinaran. Dari hasil gambar terdapat empat bagian citra pada distribusi dosis pengukuran dengan octavius 4D pada bagian kiri atas, hasil dari distribusi dosis TPS berada pada sudut kiri bawah, kedua distribusi dosis tersebut akan dilihat pada distribusi dosis yang sudah digabungkan antara pengukuran dan perhitungan pada TPS terletak pada sudut kanan atas. Pada profil tersebut merupakan profil distribusi dosis pada sumbu $\mathrm{Y}$ terhadap sumbu $\mathrm{X}=0$, pada awal kurva mengalami kenaikan dan akhir kurva mengalami penurunan yang merupakan batasan antara daerah yang tidak mendapat radiasi dengan daerah yang mendapatkan radiasi yang merupakan lapangan penyinaran IMRT, pada daerah tengah merupakan distribusi dosis pada setiap lapangan penyinaran dimana dosisnya bervariasi sehingga kurva yang terbentuk terjadi fluktuasi yang mencolok. Pada bagian kanan bawah merupakan gambaran nilai gamma pada $5 \%$ dose different (DD) dan $3 \mathrm{~mm}$ Dose to Agreement (DTA). Pada setiap lapangan penyinaran pasien kanker lidah 1 kesesuaian piksel dengan kriteria nilai $(\gamma \leq 1)$ pada $5 \% \mathrm{DD}$, dan $3 \mathrm{~mm}$ DTA, dapat dilihat pada tabel 1 .

TABEL 1. Merupakan hasil verifikasi penyinaran IMRT protokol pasien 2 pada setiap lapangan penyinaran

\begin{tabular}{|c|c|c|}
\hline $\begin{array}{c}\text { Lapangan } \\
\text { Penyinaran }\end{array}$ & $\begin{array}{c}\text { Total Monitor Unit } \\
\text { (MU) }\end{array}$ & $\begin{array}{c}\text { Kesesuaian } \\
\text { Nilai piksel }\end{array}$ \\
\hline 1 & 59,7 & 96,8 \\
\hline 2 & 46,5 & 86,0 \\
\hline 3 & 46,9 & 96,2 \\
\hline 4 & 76,0 & 97,8 \\
\hline 5 & 84,8 & 98,5 \\
\hline 6 & 30,5 & 96,3 \\
\hline 7 & 30,7 & 93,9 \\
\hline
\end{tabular}

Dari hasil verifikasi setiap lapangan penyinaran terdapat nilai kesesuaian piksel kurang dari 90 $\%$ yaitu pada lapangan penyinaran 2 pada verifikasi protokol pasien kanker lidah, dimana nilai yang didapat adalah $86,0 \%$, untuk lebih jelas dapat dilihat pada gambar 4 .

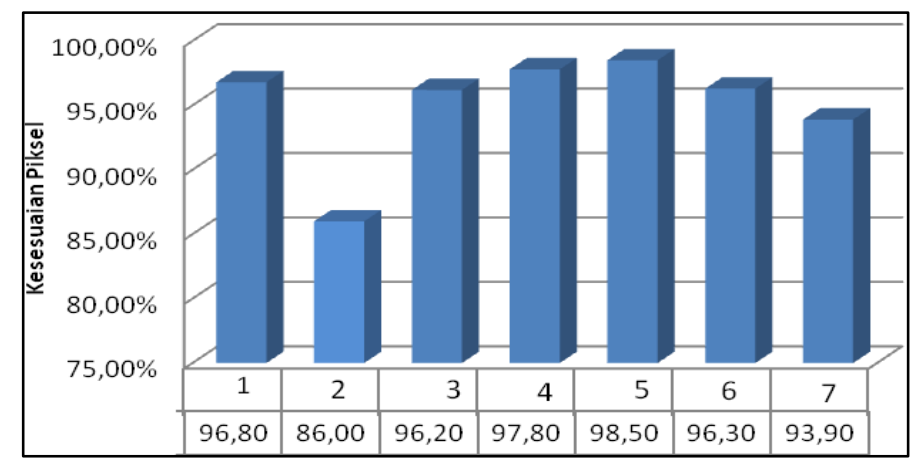

GAMBAR 4. Grafik kesesuian piksel protokol penyinaran pada pasien 1 dengan $(\mathrm{y} \leq 1)$ pada $5 \%$ DD dan $3 \mathrm{~mm}$ DTA.

Pada tiap - tiap lapangan penyinaran menghasilkan distribusi dosis yang berbeda - beda dalam penyinaran disebabkan karena modulasi intensitas radiasi dengan pergerakan MLC. Nilai kesesuaian piksel yang paling rendah terdapat pada lapangan penyinaran 2 mendapatkan hasil 
86,0 \%. Hasil kesesuaian piksel yang diperoleh, merupakan perbandingan dari perencanaan verifikasi dari TPS pada setiap lapangan penyinaran verifikasi kasus pasien. Penyinaran IMRT setiap lapangan penyinaran pada protokol kanker lidah pasien 2. Hasil Distribusi dosis dari perhitungan TPS dan pengukuran menggunakan Octavius 4D pada setiap lapangan penyinaran pasien kanker lidah 2 kesesuaian piksel dengan kriteria nilai $(\gamma \leq 1)$ pada $5 \%$ DD, dan $3 \mathrm{~mm}$ DTA.

TABEL 2. Merupakan hasil verifikasi penyinaran IMRT protokol pasien 2 pada setiap lapangan penyinaran

\begin{tabular}{|c|c|c|}
\hline $\begin{array}{c}\text { Lapangan } \\
\text { Penyinaran }\end{array}$ & $\begin{array}{c}\text { Total Monitor Unit } \\
\text { (MU) }\end{array}$ & $\begin{array}{c}\text { Kesesuaian } \\
\text { Nilai piksel }\end{array}$ \\
\hline 1 & 59,7 & $97,8 \%$ \\
\hline 2 & 46,5 & $95,1 \%$ \\
\hline 3 & 46,9 & $94,2 \%$ \\
\hline 4 & 76,0 & $97,9 \%$ \\
\hline 5 & 84,8 & $98,5 \%$ \\
\hline 6 & 30,5 & $88,2 \%$ \\
\hline 7 & 30,7 & $96,2 \%$ \\
\hline
\end{tabular}

Dalam hasil verifikasi setiap lapangan penyinaran terdapat nilai kesesuaian piksel kurang dari $90 \%$ yaitu pada lapangan penyinaran 2 pada verifikasi protokol pasien kanker lidah, dimana nilai yang didapat adalah $86,0 \%$, untuk lebih jelasdapat dilihat pada gambar 5 .

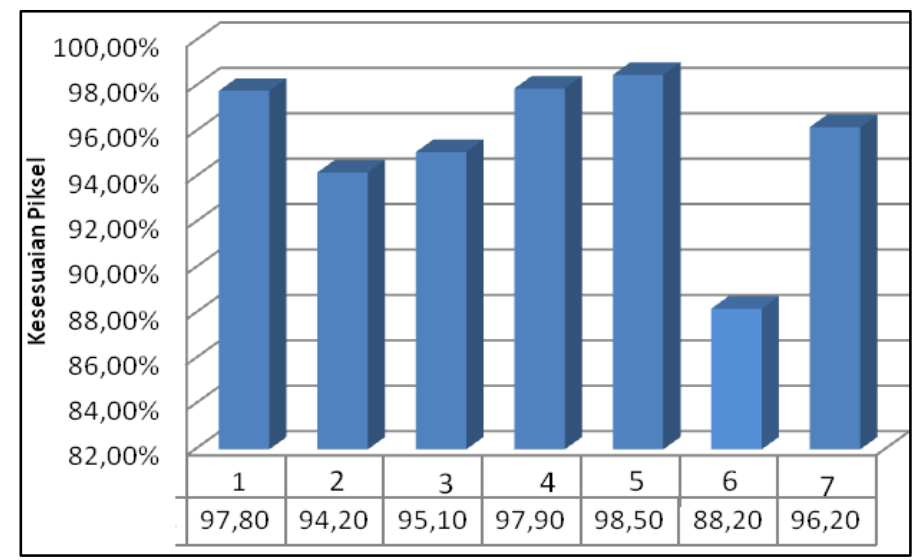

GAMBAR 5. Grafik kesesuian piksel protokol penyinaran pada pasien 2 dengan $(\mathrm{y} \leq 1)$ pada $5 \%$ DD dan $3 \mathrm{~mm}$ DTA.

Dari verifikasi yang dilakukan untuk semua lapangan penyinaran gambaran distribusi dosis yang dihasilkan lebih homogen bila dibandingkan dengan verifikasi untuk setiap lapangan penyinaran karena menggunakan akumulasi dari 7 lapangan penyinaran. Setelah dilakukan verifikasi ada beberapa bagian yang memiliki nilai $(\gamma>1)$ yang mengakibatkan nilai kesesuaian piksel berkurang yang disbabkan oleh beberapa faktor diantaranya kelembaban dan tegangan arus yang tidak stabil mengakibatkan kesalahan pada koreksi dosis di detektor Octavius 4D, beberapa sinar yang mempunyai energy cGy yang sangat kecil sehingga mengakibatkan perbedaan yang sangat kecil akan mempengaruhi persentase yang besar, sedangkan pembacaan detektor bukan pada titik perhitungan pada TPS. Karena pergerakan MLC secara dinamis untuk mengatur intenitas radiasi yang diberikan. Secara keseluruhan hasil verifikasi menggunakan Octavius 4D dengan menggunakan teknik IMRT bagus karena mempunyai kesesuaian piksel semua lapangan penyinaran pasien 1 hasil yang didapat adalah $99,7 \%$ dan semua lapangan pasien 2 hasil yang didapat adalah $98,4 \%$. Untuk hasil dari kesesuaian piksel setiap lapangan penyinaran didapat hasil kesesuaian piksel sebagai berikut pasien $1: 96,8 \%, 86,0 \%, 96,2 \%$, 97,8 \%, 98,5 \%, 96,3\%,93,9\%, dan untuk pasien $2: 97,8 \%, 94,2 \%, 95,1 \%, 97,9 \%, 98,5 \%$, $88,2 \%, 96,2 \%$.

Hasil verifikasi dengan menggunakan Octavius 4D teknik IMRT untuk verifikasi setiap lapangan penyinaran masih kurang baik dimana terdapat sebagian penyinaran masih mendapatkan kesesuaian piksel $<90 \%$ penyebabnya mungkin karena energi dan distribusi 
dosis yang diterima berbeda beda tiap lapangan penyinaran dan pergerakan MLC secara dinamis untuk mengatur intensitas radiasi yang diberikan dimana untuk mendapatkan dosis seminimal mungkin pada organ sehat dan dosis yang maksimal yang diterima pada organ target tumor.

Hasil verifikasi dengan menggunakan Octavius 4D teknik IMRT untuk verifikasi yang dilakukan untuk semua lapangan penyinaran gambaran distribusi dosis yang dihasilkan lebih homogen bila dibandingkan dengan verifikasi untuk setiap lapangan penyinaran karena menggunakan akumulasi dari 7 lapangan penyinaran dengan kriteria nilai $(\gamma \leq 1)$ pada $5 \%$ DD, dan 3 mm DTA.

\section{KESIMPULAN}

Dari hasil penelitian yang telah dilakukan tentang verifikasi perencanaan IMRT menggunakan Octavius 4D yang dilaksanakan di Rumah Sakit Gading Pluit Jakarta, telah dilakukan verifikasi penyinaran dengan Octavius 4D dengan hasil untuk verifikasi semua lapangan penyinaran untuk pasien 1 didapat kesesuaian piksel 99,7 dan pasien 2 didapat kesesuaian piksel 98,4\%. Untuk verifikasi setiap lapangan penyinaran memepunyai kesesuaian piksel pasien $1 ; 96,8 \%, 86,0 \%$, $96,2 \%, 97,8 \%, 98,5 \%, 96,3 \%, 93,9 \%$, pasien 2 ; 97,8 \%, 94,2 \%, 95,1\%, 97,9\%, 98,5\%, $88,2 \%, 96,2 \%$. Perbedaan pengukuran disebabkan antara lain karena pergerakan MLC secara dinamis, tegangan arus yang tidak stabil, temperatur ruangan yang selalu berubah - ubah dan daerah dosis rendah.

\section{REFERENSI}

[1] Stephens, F.O., \& Aigner, K.,R. 2009. Basic of oncology. 2009th edition

[2] Velde, Van de C. J. H., Bosman, F.T., Wagener, D. J. Onkologi. Ed. 5. Yogyakarta : Gadjah Mada University Press. 1999

[3] Ryangga, D. 2011. Optimasi pencitraan lokalisasi dengan computed radiografi (CR) pada pasien radioterapi dengan berkas sinar-x 6MV. Tesis. Fakultas Matematika dan Ilmu Pengetahuan Alam, Universitas Indonesia, Jakarta

[4] Todorovic, M., Fischer, M., Cremers, F., Thom, E., dan Schmidt, R. 2006. Evaluation of GafChromic EBT prototype B for external beam dose verification. Medical physics

[5] Kristina, D. 2012. Verifikasi penyinaran IMRT menggunakan film gafchromic. Skripsi. Fakultas Matematika dan Ilmu Pengetahuan Alam, Universitas Indonesia, Jakarta.

[6] Warjono, S. 2012. Verifikasi lapangan radiasi linac menggunakan kaset non screen yang dimodifikasi lapisan $\mathrm{Pb}$ dan Zn pada film sinar-x. Jurnal Teknik Elektro Terapan. Vol. 1(2): 2632.

[7] Wahyu, E. 2008. Sebuah penelitian tentang perbandingan dosis pada simulasi radioterapi paru paru antara hasil kalkulasi TPS dengan pengukuran. Fakultas Matematika dan Ilmu Pengetahuan Alam, Universitas Indonesia, Jakarta

[8] Pinborg, J.J. 1991. Kanker dan Prakanker Rongga Mulut, .Ed.ke-1. Penerbit Buku Kedokteran EGC. Jakarta

[9] Bushong ,S. 1988, Radiologic Science For Technologist, fourt edition. C.V . Mosby Company. Washington

[10] Khan F.M. 2003. , The physics of Radiation Therapy, Lippincott Wiliams. Englan5013

[11] Murat B, Gokan O., dan Cuneyt E. 2010. Besic Radiation Oncology.nSpringer Berlin

[12] Jacob D. 2011 Treatmen Planning, IAEA

[13] Metcalfe P., Kron T., dan Hoban P. 2007. The Physics of Radiotherapy X - Rays and Electrons. Medical Physics Publishing, Madison, Wiconsin

[14] IBA Dosimetry AB 2012 Octavius 4D User's Gruide England

[15] Mijnheer dan George.2008. Guidelines for the Verification of IMTR. ESTRO 